\title{
The Levi O. Leonard Railroad Collection
}

\author{
RICHARD M. KOLBET
}

In December of 1932 the University of Iowa Graduate College granted to Levi O. Leonard, former historian of the Union Pacific and Rock Island Railways, an honorarium of eighty dollars per month for one year "for classifying, indexing, and putting into proper shape for the students of history, a collection of printed and manuscript material, documents, newspaper clippings, etc., in the possession of Mr. Leonard ..., which material he will bring to Iowa City to be left at the University." 1 Leonard was returning to the city of his boyhood memories where, in 1860, his father, Nathan R. Leonard, had been appointed the first full professor at the University of Iowa's Department of Mathematics; ${ }^{2}$ where, as a small boy in 1869 , he had heard news of the completion of the first transcontinental railroad tapped out on the telegraph wire; and where, in 1871, he first enrolled at The University of Iowa. After two years of intense study his eyes had so weakened that he was forced to give up his formal education. Not to be discouraged, however, he soon became interested in the rapidly expanding railroad industry.

Leonard's first association with railroading came in 1879 when, under the close scrutiny of his father, who was also City Engineer, he helped survey the right of way for the Burlington, Cedar Rapids and Northern Railroad through Iowa City. Early in 1880 at Cheyenne, Wyoming, L.O., as his friends called him, was hired by the Union

\footnotetext{
${ }^{1}$ Iowa. State Board of Education. Finance Committee. Minutes. December 14, 1932.

2 Iowa Alumnus, Vol. 1, No. 2 (February, 1904) pp. 25-27; also "Nathan R. Leonard," The National Cyclopaedia of American Biography, Vol. 25, p. 227. In 1866 and again in 1870 Nathan Leonard was named acting president of The University of Iowa. In 1898 he was appointed the first president of the newly created Montana School of Mines in Butte, Montana.
} 
Pacific Railroad as a civil engineer. Later that year he was assigned to help in the construction of the Utah and Northern Railroad, the first line to reach Montana. Between March and November of 1881, Leonard was car clerk in the Cheyenne, Wyoming, freight office and, as he stated, "was often impressed into train service running an extra freight over the hill from Cheyenne to Laramie or a freight down to Sidney and North Platte."3

In 1884, having resigned his position with the Utah and Northern, Leonard settled in Anaconda, Montana, where he purchased a newspaper, the Anaconda Weekly Review. Ten years later he left Anaconda for Butte, where he renamed his newspaper the Mining and Railroad Review. In the fall of 1897 he sold that paper and returned to the transportation industry as a traveling freight agent for the Missouri Pacific Railroad.

Leonard remained with the railroad industry in various capacities until 1918 when, at the suggestion of E. E. Calvin, vice-president of the Union Pacific, he wrote numerous sketches on the organization and construction of the first transcontinental railroad, which were syndicated in the newspapers of Utah, Montana, and Idaho. In 1921, his accomplishments as journalist-historian were rewarded when Calvin appointed him the official historian of the Union Pacific.

In his new position Leonard was able to devote most of his time to gathering the records of the men who had constructed the Union Pacific and relating their accounts in the Union Pacific Magazine. In a letter to John S. Worley, Curator of the University of Michigan Transportation Library, Leonard described what he had collected during his first six months as historian:

Have a short article written by the late Bishop Daniel S. Tuttle, of Missouri, about his first trip over the Union Pacific when the line was out of Omaha 275 miles. An envelope with 75 to 80 pages, typewritten, incidents of construction days, by W. B. Doddridge, first operator at Columbus, Nebu, and later general superintendent of the Union $\mathrm{Pa}$ -

3 Leonard to Frank E. Calvin. September 26, 1938. The original of this letter and of the other letters quoted elsewhere in this essay are presently in the Leonard Collection at Iowa.

4 While employed by the Union Pacific, Leonard was a regular contributor to this magazine, having written two series of articles for it, "Past Presidents of the Union Pacific" and "Builders of the Union Pacific." After his resignation in 1924 he occasionally contributed articles to it until April, 1933, when it ceased publication. Among these contributions may be singled out "The First Rail Road Entering Montana" (June, 1926) and "An Indian Raid at Sidney. Nebraska, in 1870" (March, 1933). 
cific and for 12 years vice-president and general manager of the Missouri Pacific Railroad at St. Louis. . . Quite a number of pages of incidents by W. N. Shilling who was the telegraph operator at the driving of the golden spike at Promontory, Utah, May 10, 1869. A letter of sketches by R. T. Hilliard, first agent at Sidney, Neb., in 1868. A large package of about 60 large photo views and two hundred or more stereo views along the Union Pacific. ${ }^{5}$

In addition, Leonard had contacted some twenty-three other engineers, construction foremen, and crew members who were willing to share their experiences.

To Leonard, however, the "most valuable and important historical find" he had made during his earlier years as historian was the collection of letters, telegrams, profile maps, and copy books of Samuel B. Reed. ${ }^{6}$ Leonard had first heard of Reed's manuscripts from his cousin in July, 1921. By December of that year he had convinced the Reed descendants of the importance of preserving these historical records. At first, Reed's daughters considered them too sacred to give away, permitting him to copy only what was of value to the Union Pacific, provided he delete all personal and family matters. ${ }^{7}$ Early in 1922, however, they gave Leonard the papers "without reserve."

Leonard was now convinced that he had "all the data necessary to write an absolute accurate history of the true story of the building of the Union Pacific."9 His enthusiasm, however, was not shared by all, especially the recently appointed officers of that company. This lack of interest did not discourage Leonard, for he continued to collect and compile with the expressed intent of publishing his findings. It was during this research that the historian discovered that many of the men involved with the construction of the Union Pacific were also the managers or contractors, engineers or crew members of other important railroads. In a letter to Charles E. Fisher, President of the Railway and Locomotive Historical Society, he discussed the phenomenal development of his discovery:

I first gathered the data [of the] Union Pacific finding that the men who organized and built it and responsible for its success were men

5 Leonard to John S. Worley, July 24, 1931.

6 Reed, the first superintendent of construction of the Union Pacific and later a noted civil engineer, began work with that railroad at the laying of the first track in Omaha in 1864, and continued with the Union Pacific several months after completion of the line at Promontory, Utah, in 1869.

7 Leonard to E. E. Calvin, July 7, 1921.

${ }^{8}$ Leonard to E. E. Calvin, February 7, 1922.

9 Ibid. 
who founded the Rock Island and Pacific. $\left[{ }^{10}\right]$ The early history of the men who founded the Rock Island and Pacific were the men who brought Chicago its first railroad, March 22, 1852, the Michigan Southern and Northern Indiana Railroad. Following up that data I found that the men who were on the Erie Canal enlargement, in 1841 and before that on the little railroad from Albany to Schenactady [sic], of only 17 miles, were also following the lines west. Just another half step brings out the fact that the engineers who were on the enlargement of the Erie Canal in 1841 were the men associated with the movement which resulted in the first trans-continental line. ${ }^{11}$

Because of this close interrelationship of the Union Pacific and Rock Island, and because of the increasing lack of support of the railroad officials regarding his book, Leonard resigned as historian for the Union Pacific and accepted the position of Special Historical Research Representative with the Rock Island. ${ }^{22}$ As in his former position, Leonard continued to collect records of the railroad industry. He contributed articles to the Rock Island Magazine ${ }^{13}$ and also traveled extensively on the route of the Rock Island, lecturing on the history of that line. He illustrated his talks with the five hundred or more lantern slides he had accumulated.

As Leonard continued to gather more material, he noticed that the name of one of the most important individuals in railroad history kept recurring-Dr. Thomas C. Durant. Durant, the first vice-president and general manager of the Union Pacific, and the first president of the Credit Mobilier of America, was considered to be the initial force behind the inception, organization, and construction of the transcontinental railroad. Leonard felt that without Durant's papers he could proceed no further. His effort to locate the magnate's heirs proved futile until 1926 when, as a result of one of his many articles in the Rock Island Magazine, he received a letter from a man in North Carolina who knew the address of Durant's only son, William West Durant. The young Durant, with his wife, Annie C. Durant, was living in a

${ }^{10}$ Earlier known as the Mississippi and Missouri Railroad.

11 Leonard to Charles E. Fisher, September 17, 1936.

12 Carl R. Gray, president of the Union Pacific, wrote Leonard on January 19. 1924, stating that the Union Pacific was no longer interested in publishing a history and would not authorize or endorse anyone else who was interested. The reasons he gave were that the works available were accurate and authentic; interest in railroad history was exhausted; and that Leonard's work might cause "material embarrassments."

13 In addition to his two regular series, "Founders and Builders of the Rock Island" and "Famous Homes on the Rock Island Lines." Leonard also contributed several articles of special historical interest, e.g. "Early Days in Rock Island" (November, 1927); "First Railroad Built into Des Moines" (January, 1928); “Abraham Lincoln as a Prophet” (February, 1928). 
modest half-basement apartment in New York's West Central Park district. ${ }^{14}$

Leonard's first letter to William Durant brought the following response:

I am Dr. Durant's only son-am 76 years of age-and if I could see you, it would facilitate furnishing data regarding his connection with the Rock Island R. R., and Mr. Farnham [i.e. Farnam]. I have stored away some books of "Farnham and Durant" and other documents referring to the matter, but I don't see how, unless you are in New York, you can really get what you want. I have Union Pacific data which conclusively show Dr. Durant was a real active builder of that R. R. . . . ${ }^{15}$

Upon receipt of this letter, Leonard immediately took a leave of absence from the Rock Island Railroad and went to New York. The result of that interview and the correspondence which followed for the next five years can best be summed up in the reported statement of Durant:

Mr. L. many parties have been here to get these records, but you are the only man that I've ever met who is as familiar with that situation out there and I'm going to give you all the records and data that I have and I hope you make a million dollars out of the history and I know you will do justice to my father's memory. ${ }^{16}$

And so, in 1930, about the time Leonard first wrote to The University of Iowa seeking a possible publisher for his book, W. W. Durant sent him approximately ten boxes of Thomas C. Durant's manuscripts. Included in this collection, estimated at 1,000 pounds, were profile maps, ledgers, lists of stockholders, estimates of expenditures, contracts, balance sheets, cost analyses, and hundreds of letters and telegrams concerning the Mississippi and Missouri, Rock Island and Pacific, Union Pacific, Eastern Division, and Union Pacific Railroads for the period 1850-1900. Some of the more important single items that Leonard discovered were: letter and telegram impression books of T. C. Durant, July, 1853-January, 1873; the day book for the Union Pacific contractors, the Casement brothers, 1866-1868; a journal of the Union Pacific, 1863-1865; contract and account book of the Union Pacific, 1864-1865; and T. C. Durant's private ledger, 18531869. The collection also included over 5,000 telegrams sent to Durant by members of his Washington lobby, who were acting under his instructions to secure passage of the 1862 "Act to aid in the construction of a railroad and telegraph line from the Missouri River to the

${ }^{14}$ Leonard to his brother, Charles R. Leonard, August 26, 1938.

15 W. W. Durant to Leonard, April 7, 1926.

16 Leonard to his brother, Charles R. Leonard, August 26, 1938. 
Pacific." Other items of interest were: the original Hoxie contract; ${ }^{17}$ the original Ames contract; ${ }^{18}$ minutes of various board meetings of the Union Pacific and Union Pacific, Eastern Division. Correspondents in the hundreds of letters and telegrams, Leonard found, included such men as Abraham Lincoln, Maj. Gen. Grenville M. Dodge, James Harlan, John A. Dix, Sidney Dillon, George F. Train, J. P. Usher, O. W. Browning, Brigham Young, Henry Farnam, Joseph E. Sheffield, Oliver and Oakes Ames, and many, many others. This collection, Leonard decided, was the most complete of its kind and could never be equaled.

Shortly after receiving this wealth of manuscripts from the Durant family, Leonard wrote to his friend Benjamin F. Shambaugh, Chairman of the Department of Political Science at The University of Iowa and Superintendent of the Iowa State Historical Society in Iowa City, "wondering if there might be any interest there by the University in any such subject as transportation." 19 If the University were interested, Leonard said, he would deposit his collection there, providing they supply him with ample funds and facilities to index his papers and to write his history. It was at this time that the Graduate College granted him the honorarium as a research assistant of railroad history.

Leonard's collection, however, was not yet complete. On December 9, 1934, he received a telegram from Mrs. Annie C. Durant, which stated that while she was relocating, she had found more Union $\mathrm{Pa}-$ cific data but would destroy them if Leonard "did not value them."20 Leonard immediately went to New York and secured the supplementary papers, which he later described to Grace Hebard, Chairman of the Political Economy and Sociology Department, University of Wyoming:

On my last trip to New York, December last I found and brought back with me letters from 250 of the greatest men in America of the 1865-6 period. They include 4 members of Lincoln's Cabinet, and

17 The Hoxie contract introduced the concept of a controlled construction company and the formation of the Credit Mobilier of America.

${ }^{18}$ When Durant was having difficulties selling the bonds for the construction of the Union Pacific. Oliver and Oakes Ames. heirs to their father's multimillion dollar shovel factory in Massachusetts, supplied the financial backing. Both were influential in the affairs of the Union Pacific and the Credit Mobilier. In addition, Oliver served as president of the Union Pacific from 1866 until 1871. Oakes, a Republican congressman from Massachusetts, was censured by a resolution of the House of Representatives for his role in the Credit Mobilier scandal.

${ }^{19}$ Leonard to Benjamin F. Shambaugh, July 7, 1931.

${ }^{20}$ Leonard to Hal S. Ray, Director of Publicity, Rock Island Lines, December $18,1934$. 
President Andrew Johnson; three different members of the Sherman familt [sic]; John, William Tecumseh and Charles T.; Horace Greeley; Henry Ward Beecher; Admiral D. G. Farragut; General Geo. G. Meade, of Gettysburg; Winfield S. Hancock; Phil Sheriday? [Sheridan] R [utherford] B. Hayes; Jas. G. Blaine; C. Delano of Ohio, who seconded the nomination of Lincoln at the Chicago convention with the remark "That he is a man who knows how to split rails and maul Democrats.'

These letters have been stored in a bank vault in New York since 1866.21

It was fortunate that Leonard responded quickly to Mrs. Durant's telegram, for later she wrote:

I might have burned all those papers which mean so much to a history-I did burn 1500 lbs. we had sent to Canada saving only the U.P. out. These were letters, etc. about other roads Dr. Durant was interested in. ${ }^{22}$

To supplement his income while completing his book, Leonard again began his lecture series on the Union Pacific and Rock Island Railroads. To reach a wider audience he revised these lectures into radio talks on the history of the West. From 1935 until the summer of 1941, he presented over three hundred of these talks over stations WOC, Davenport, and WHO, Des Moines. During that period he also conducted a Friday night series, "History in Review," for The University of Iowa's radio station, WSUI.

Early in 1937 Mrs. Durant again notified Leonard that she had located more of Thomas C. Durant's manuscripts, later explaining that "these papers had turned up in a lawyer's fire-proof vault-where they evidently [had] been put years ago for safe keeping." ${ }^{23}$ Leonard immediately went to New York and discovered the most elusive and revealing documents of the Credit Mobilier of America-Union Pacific Railroad scandal. ${ }^{24}$ Included in this last lot of manuscripts were the articles of incorporation of the Credit Mobilier, financial statements, construction contracts, balance sheets, capital stock payments and

${ }^{21}$ Leonard to Grace Hebard, July 16, 1936. The letters to which Leonard refers deal primarily with the Great Pacific Railway Excursion of 1866, which celebrated the attainment of the 100th meridian. The grandiose trip was managed by T. C. Durant, who had sent invitations to the U.S. President and his Cabinet, to all members of Congress, to the foreign ministers, to the commanders of the Army and Navy, and to the leading capitalists and railroad men throughout the country. For a description of the excursion, see James McCague's Moguls and Iron Men (New York, 1964), pp. 131-136.

${ }^{22}$ Mrs. Annie C. Durant to Leonard, June 8, 1935.

${ }^{23}$ Mrs. Annie C. Durant to Leonard, January 29, 1937.

24 It is believed that these were the papers that the Union Pacific officials removed from their New York office in 1869 to avoid their confiscation by 
transfers, trial balances, and of the greatest importance, a Credit Mobilier ledger, May, 1863-June, 1868.

With the addition of these papers to his collection, Leonard now had what he considered to be the complete story of the Union Pacific. After twenty-five years of searching, at a personal cost of $\$ 20,000$, he completed his "absolute accurate history"-A Railroad to the Sea (Iowa City: Midland House, 1939). Unfortunately the book, which was co-authored by an associate, Jack T. Johnson, fell short of Leonard's dreams and, therefore, was not so great a contribution to the history of the Union Pacific as he had envisioned. ${ }^{25}$ Leonard was not discouraged, though, for he began plans to publish a history of the Rock Island Railroad as well as a history of the Credit Mobilier. Before these plans could materialize, Leonard died in March, 1942.

As a result of Leonard's lifetime dedication to and preservation of railroad history, The University of Iowa acquired one of the most complete chronicles of railroad transportation in America. ${ }^{26}$ The entire collection, including Leonard's correspondence and manuscripts of his lectures on the history of the West, is one of the most important sources for study of early railroad construction in Illinois, Iowa, Kansas, and especially for the Union Pacific from Omaha to Ogden. The letters and telegrams to and from Thomas C. Durant, vice-president and general manager of the Union Pacific and an important figure in the affairs of the Chicago, Rock Island, and other lines, are a mine of information that has some relevance to the study of practically any subject dealing with the social and economic development of the Middle West from 1850 to the period following the Civil War.

the federal government (See New York Herald, March 29, 1869 to April 6 . 1869). The papers were still missing during the Poland and Wilson Congressional investigations (U.S. Cong. House. "Credit Mobilier Investigation," 42d Cong., 3d Sess., 1873, H. R. 77, and U.S. Cong. House. "Affairs of the Union Pacific Railroad Company," 42d Cong., 3d Sess., 1873, H.R. 78, respectively). Durant used the papers, however, as a defendant during a Rhode Island lawsuit in 1879. For a history of the Credit Mobilier and the subsequent scandal which surrounded it. see Jay B. Crawford's The Credit Mobilier of America, Boston, 1880.

25 Apparently the book was reviewed in very few scholarly journals, and even then was received with mixed feelings. See E. G. Campbell's review in Mississippi Valley Historical Review, Vol. XXVII (1940), 143-44.

${ }^{26}$ In addition to Leonard's use of the collection for his book, his newspaper articles, and his sketches in the Rock Island Magazine and Union Pacific Magazine, the Leonard Collection has also been used extensively by Jack T. Johnson (Peter Anthony Dey. Iowa City, 1939) and Stanley P. Hirshson (Grenville $M$. Dodge. Bloomington, 1967) as well as by many masters and doctoral candidates. 


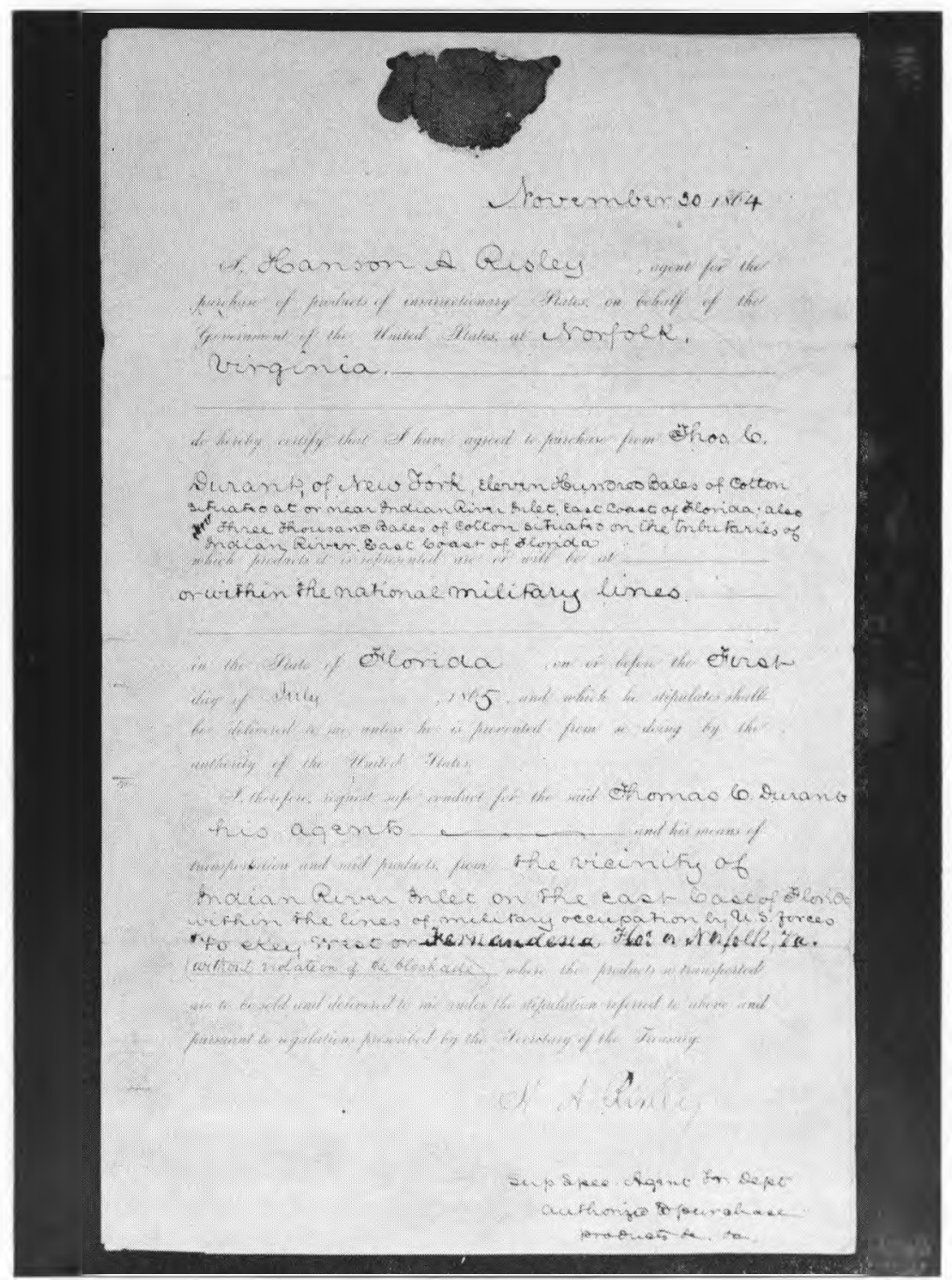

On July 2. 1864, the same day that Congress passed an amendment to the original bill for construction of the transcontinental railroad, a resolution was enacted enabling the government to purchase commodities held in insurrectionary states. In this certificate of purchase, one of some 50,000 items in the Leonard Collection. Thomas C. Durant, vice-president of the Union Pacific, is granted permission to ship cotton from Florida. 


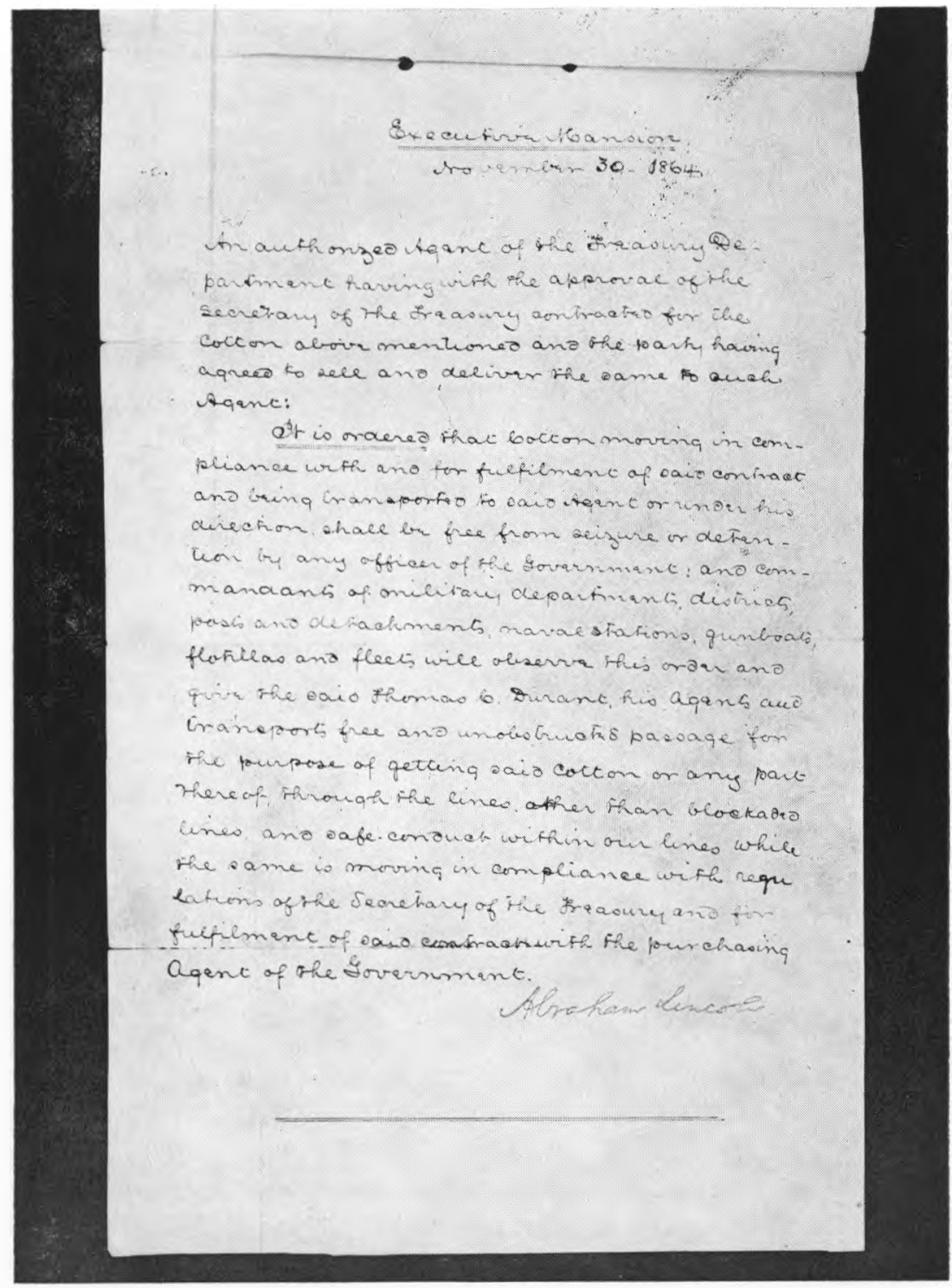

All certificates of purchase, such as the one illustrated on the preceding page, needed approval of the President of the United States. In this instance. President Lincoln's signature is appended to an executive order written on the verso of the Durant certificate. 